IZA DP No. 7576

Do House Prices Affect Consumption?

A Re-assessment of the Wealth Hypothesis

Annalisa Cristini

Almudena Sevilla

August 2013

Forschungsinstitut

zur Zukunft der Arbeit

Institute for the Study

of Labor 


\title{
Do House Prices Affect Consumption? A Re-assessment of the Wealth Hypothesis
}

\author{
Annalisa Cristini \\ University of Bergamo \\ Almudena Sevilla \\ Queen Mary University of London \\ and IZA \\ Discussion Paper No. 7576 \\ August 2013 \\ IZA \\ P.O. Box 7240 \\ 53072 Bonn \\ Germany \\ Phone: +49-228-3894-0 \\ Fax: +49-228-3894-180 \\ E-mail: iza@iza.org
}

Any opinions expressed here are those of the author(s) and not those of IZA. Research published in this series may include views on policy, but the institute itself takes no institutional policy positions. The IZA research network is committed to the IZA Guiding Principles of Research Integrity.

The Institute for the Study of Labor (IZA) in Bonn is a local and virtual international research center and a place of communication between science, politics and business. IZA is an independent nonprofit organization supported by Deutsche Post Foundation. The center is associated with the University of Bonn and offers a stimulating research environment through its international network, workshops and conferences, data service, project support, research visits and doctoral program. IZA engages in (i) original and internationally competitive research in all fields of labor economics, (ii) development of policy concepts, and (iii) dissemination of research results and concepts to the interested public.

IZA Discussion Papers often represent preliminary work and are circulated to encourage discussion. Citation of such a paper should account for its provisional character. A revised version may be available directly from the author. 


\section{ABSTRACT}

\section{Do House Prices Affect Consumption? A Re-assessment of the Wealth Hypothesis}

This paper undertakes a comparison exercise to disentangle what drives the opposite findings regarding the effect of house prices on consumption documented in two papers using the same data set for the UK. On the one hand, Campbell and Cocco (2007) find that old owners are the most benefited by a house price increase and young renters the least, confirming the so-called wealth hypothesis. On the other hand, Attanasio, Blow, Hamilton, and Leicester (2009) find that house prices have the same impact on consumption across age groups, consistent with the so-called common factor hypothesis. First, we confirm that the findings in both papers can be reproduced. Second, we rule out a number of potential reasons related to the basic data construction, and provide evidence that the functional form (i.e., an Euler equation of consumption vs. a reduced form life-cycle model) and not data aggregation considerations (household level data vs. synthetic cohort data) may be at the root of the conflicting results in the two papers. Our findings revive the debate of whether there is an effect of house prices on consumption.

\section{JEL Classification: D13}

Keywords: consumption, house prices, wealth hypothesis, common factor hypothesis

Corresponding author:

Annalisa Cristini

Department of Economics

Via dei Caniana 2

24100 Bergamo

Italy

E-mail: annalisa.cristini@unibg.it

\footnotetext{
* We thank Martin Browning and John Muellbauer for support. We thank the authors John Campbell and Joao Cocco, and Orazio Attanasio and Andrew Leicester, who kindly agreed to let us have their data sets and the code to replicate their results, and who diligently answered all our queries.
} 


\section{Introduction}

This paper looks at the validity of the wealth and the common factor hypotheses as alternative explanations to the relationship between changes in house prices and consumption in the UK. The wealth hypothesis suggests that rising house prices stimulate consumption by increasing households' perceived wealth. In contrast, the common factor hypothesis supports the fact that both, rises in house prices and consumption, are driven by common factors. Housing is the dominant component of wealth for the typical household in the United Kingdom. Banks and Tanner (2002) report that real estate accounted for $35 \%$ of aggregate household wealth in the UK in the mid 1990s, and more recent estimates suggest that in 2006-08 this figure rose to 39\% (e.g., ONS 2009). House prices also exhibit high levels of volatility, especially in the UK. Nominal house prices ranged from -10\% to 30\% between 1988 and 2000 (e.g., Campbell and Cocco 2007). Given the drop in nominal house prices during the last economic crisis (www.nationwide.co.uk), understanding whether house prices affect consumption, and if so, the nature of this relationship, is therefore crucially important.

Using the UK Family Expenditure Survey (UK FES) we look at two influential papers which, although posing a common research question, end up reaching opposite conclusions. On the one hand, Campbell and Cocco (2007) (CC thereafter) compare individuals across different agehomeownership status groups, and find that homeowners (especially old age homeowners) are advantaged by a rise in house prices. The authors interpret this result as supporting evidence for the wealth hypothesis because owners are more likely to benefit by a house price increase, particularly old age homeowners who are likely to have higher home values. ${ }^{1}$ On the other hand, Attanasio, Blow, Hamilton, and Leicester (2009) (ABHL thereafter) find that house prices do not help much in explaining consumption and, in any case, have the same impact on consumption across age groups and homeownership status groups. According to these authors these findings suffice to discard the wealth channel hypothesis in favor of the common factor hypothesis. Moreover, ABHL find that the effect of house price growth on consumption does differ across age groups but it is the young that benefit most in this case, again contrary to the wealth hypothesis. ABHL conclude that the co-movement of house prices and consumption is likely to be caused by productivity growth, and that the longer life horizon of the young explains why

\footnotetext{
${ }^{1}$ Although not explicitly discussed here, increased house prices can also impact total expenditure through improved collateral rather than directly (e.g., Browning, Gortz, and Leth-Petersen 2011, Leth-Petersen 2010).
} 
they can consume relatively more out of a house price surge. ${ }^{2}$

What is intriguing of this debate is that these somehow contradictory results regard the same country, the UK, and are based on the same data set, the UK Family Expenditure Survey (FES). Although both papers test the same underlying theory, their methodologies are remarkably different. Some immediately acknowledgeable and potentially relevant differences relate to the time period investigated (CC's analysis spans from 1988 to 2001, considering the post-financialliberalization years only, while ABHL's analysis includes all years from 1978 onwards), the type of expenditure considered (total non-housing in ABHL, non-durable in $\mathrm{CC}$ ), the inclusion or otherwise of income and interest rate in the analysis, and the way in which the price deflator is constructed. More importantly, while CC compare groups of individuals of different ages and homeownership status simultaneously, ABHL draw their conclusions by focusing mainly on the age dimension.

Our empirical strategy consists of applying the necessary changes to ABHL's specification to ultimately arrive to the CC's specification and results. First, we confirm that the findings in both papers are possible to reproduce. Second, we rule out a number of potential reasons related to the basic data construction. We rule out that differences between the two papers are driven by the different periods considered in the two papers and, in particular, by the phase of financial liberalization after 1988. In fact, we show that ABHL's findings regarding the effect of house prices on the consumption of older and younger households are robust to changes in the sample period, changes in the definition of consumption, and changes in the data source (both, house price data and expenditure data). Moreover, although the magnitude of ABHL's coefficients is sensitive to the type of deflator used, the qualitative implications remain unchanged. We also rule out that endogeneity bias arising from constructing synthetic cohorts on the basis of home ownership status as in $\mathrm{CC}$ is the cause of the different results found in the two papers. Results from estimating an Euler equation specification on synthetic-cohort level data constructed on the basis of year of birth (a strictly exogenous variable), rather than year of birth and homeownership status as in CC, are also consistent with the wealth hypothesis and do not bring the results in the two papers closer to each other.

\footnotetext{
${ }^{2}$ The source of the shock matters when analyzing the welfare effects of housing prices on aggregate consumption. For example Kiyotaki, Michaelides, and Nikolov (2011) show in a general equilibrium life cycle model that net house buyers (such as young renters) lose, and net house sellers (such as older homeowners) win from a hike in house prices derived from either a productivity shock or a drop in the world interest rate. However, whereas productivity shocks generate welfare gains (because winners can compensate losers in the housing market), the decrease in the world interest rate does not.
} 
In the last section of the paper we provide evidence that the opposite results may relate to the different ways to approximate the consumption function when a closed form solution is not possible. We first compare results across different data structures (household-level vs synthetic cohort-level), while maintaining the functional form constant (levels specification as in ABHL). Second, we compare results across estimation methods (levels as in ABHL vs Euler equation as in $\mathrm{CC}$ ), while keeping the data structure constant (synthetic cohorts constructed on the basis of year of birth). We find that whereas the different ways to aggregate the data cannot explain the opposite results obtained in the two papers, changing the functional specification can. In particular, when using synthetic-cohort level data we find that results from the level estimation are consistent with the common factor hypothesis, whereas results from the Euler equation estimation are consistent with the wealth hypothesis. These findings are analogous to those in Browning, Deaton, and Irish (1985) and suggests that the year to year changes within cohorts captured by the Euler equation specification used by CC, differ from the life cycle variation across cohorts captured by the levels specification used by ABHL. On the whole, it seems that the functional form (i.e., an Euler equation of consumption vs. a reduced form life-cycle model) and not data aggregation considerations (household level data vs. synthetic cohort data) may be at the root of the conflicting results in the two papers.

Our paper contributes to a vivid and ongoing debate in the literature about the effect of house prices on consumption and highlights the importance of replication in empirical economic research (e.g., Dewald, Thursby, and Anderson 1986, Hamermesh 2007). ABHL's results in favor of the common causality hypothesis confirm the results previously found by one of the authors when looking at an earlier period in the UK (e.g., Attanasio and Weber 1994). CC's findings in support of the wealth hypothesis add to a series of recent papers that use aggregate data on house prices and consumption (e.g., Case, Quigley, and Shiller 2001, Ludwig and Slok 2004), and support the suggestion by Muellbauer and Murphy (1990) that the boom in UK's consumption was due to a wealth effect from increased real house prices subsequent the financial liberalization that took place in the late 1980s in the UK. By being able to replicate both sets of results using the same micro evidence we are able to disentangle the strength and weaknesses of both hypotheses.

The paper is organized as follows. Section 2 describes our comparison exercise. Section 3 presents our main results and Section 4 investigates the role of data aggregation versus the 
functional form in explaining the conflicting results in the two papers. Section 5 concludes.

\section{Empirical Strategy}

Our comparison strategy starts from one paper's specification and results, and applies the necessary changes to arrive to the other paper's specification and ultimately the other paper's results. Our exercise focuses on the benchmark regression results for homeownership cohorts presented in Column (iv) of Table 4 (page 604 in Campbell and Cocco (2007)) and on the results presented in Column (III) of Table A.2 (pages 45-46 in Attanasio, Blow, Hamilton, and Leicester (2009)). Table 1 outlines the main differences between the two papers and provides a guidance to our comparison strategy. Table 1 can be read from left to right (from CC's results to ABHL's results) or from right to left (from ABHL's results to CC's results). For expositional purposes, we choose to present the comparison exercise as going from ABHL's results to CC's results.

ABHL's framework is based on a simple version of the life-cycle model, where household consumption (in levels) in each period is given by a fraction of lifetime wealth that depends only on age so that:

$$
X_{t}=\kappa(\text { age }) W \exp \left(\varepsilon_{t}\right)
$$

where where $X_{t}$ is the household consumption expenditure at time $t, W$ is the household's lifetime wealth and $\varepsilon_{t}$ is a residual term. $W$ includes human wealth (discounted lifetime earnings), net financial wealth, pension and housing wealth. The function $\kappa($ age) captures several factors, including the age composition of the household (and therefore the distance from the

end of their lives), changes in household needs and changes in discount factors (which could be induced by changes in the probability of death). They capture some of these factors using observable variables (such as family size and composition), while they proxy others with a flexible function of age. Variation between different cohorts of non-housing lifetime wealth is captured by cohort dummies. As ABHL concede, Equation 1 should be interpreted as only an approximation given that it is typically impossible to obtain a closed-form solution for consumption from a standard life-cycle model except under very strong and unattractive assumptions (such as quadratic utility). 


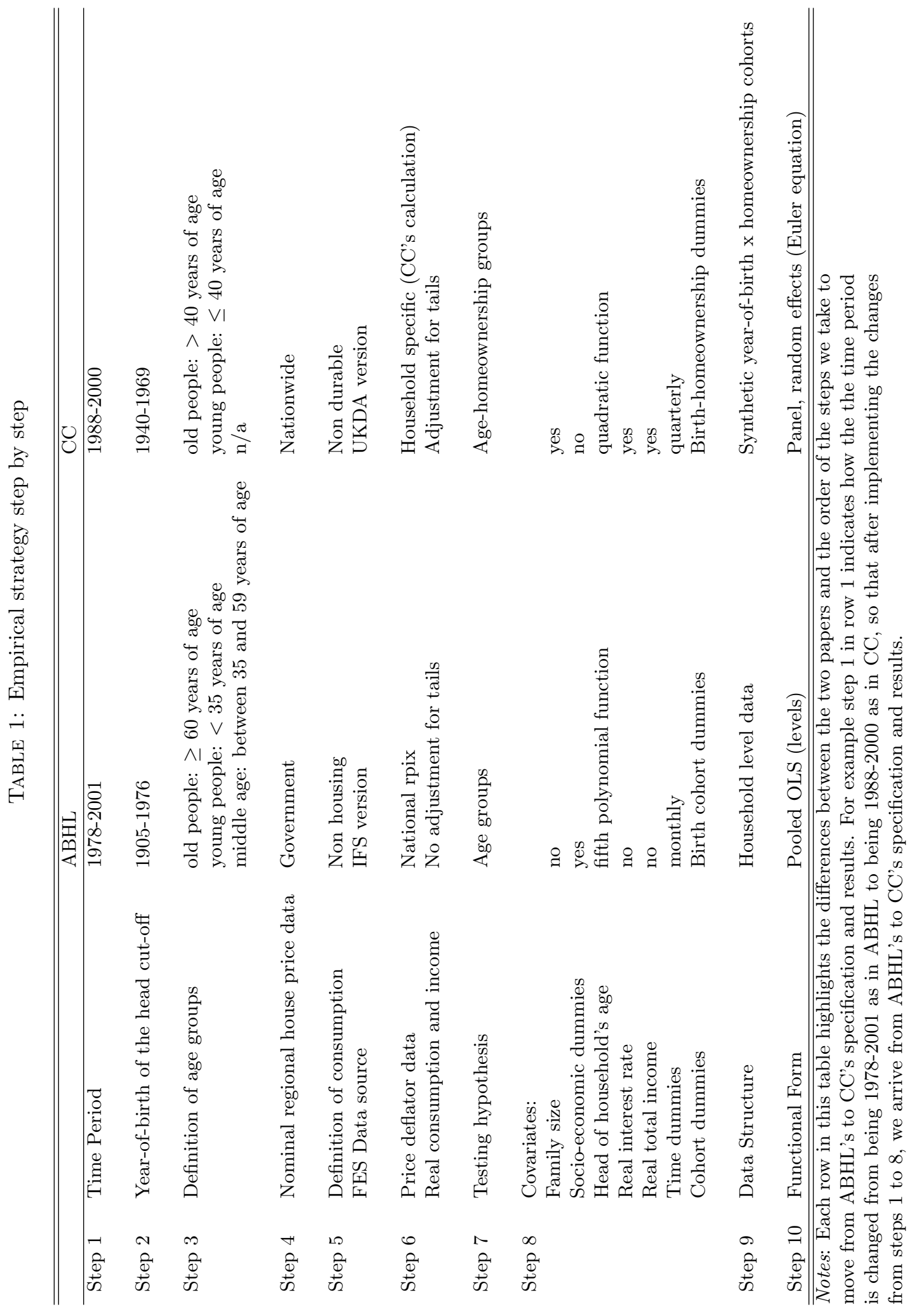


Once the level of regional house prices $\left(h_{t}^{r}\right)$ are included in the regression, and after some manipulation of Equation 1, the final specification estimated by ABHL on monthly data (Equation 6 in page 32 of ABHL) becomes: ${ }^{3}$

$$
\ln X_{t}^{c h}=\alpha_{c}+f\left(a g e^{c}\right)+\gamma^{\prime} z_{t}^{c h}++\theta_{Y} h_{t}^{r} D Y_{t}^{c h}+\theta_{M} h_{t}^{r} D M_{t}^{c h}+\theta_{O} h_{t}^{r} D O_{t}^{c h}+\varepsilon_{t}^{c}+\mu_{t}^{c h}
$$

where subscripts $t$ refer to the year-month combination, superscripts $c h$ denote household $h$ belonging to year-of-birth cohort $c$, and $\mu_{t}^{c h}$ is the household's deviation from the year-of-birth cohort average. By observing several cohorts over a long period of time, it is assumed that consumption innovations $\varepsilon_{t}^{c}$ average out to zero over time. Given appropriate normalization of the coefficients, the average $(\log )$ lifetime wealth of households belonging to year-of-birth cohort $c$ is $\alpha_{c}$. The vector $z$ includes socio-economic characteristics at the household level, e.g. family size and composition as described below in step 8, that capture some of the age and other effects on consumption, as well as monthly dummies. $h^{r}$ are regional house prices and the dummies $D Y, D M$ and $D O$ indicate the age group to which the household belongs. As ABHL note, the coefficients on house prices cannot be interpreted as the causal effect of house prices on consumption, as they may also reflect common factors. Instead, by comparing the coefficients across age groups, they make the identifying assumption that, if house prices capture the direct wealth effect, the coefficient would be expected to be larger for older consumers, who have higher rates of homeownership. In contrast, if house prices capture differences in economic activity, and in particular expected future income, the effect would be greater for younger consumers, who stand to gain the most. In some specification, ABHL compare the effect for homeowners and renters, where age dummies are replaced by those for tenure status.

Step 1 in our comparison exercise modifies ABHL's original specification and restricts the sample period of their analysis from 1978 until 2001 to the same period used by CC from 1988 until 2000. The longer period could be problematic on two fronts. First, the UK underwent a phase of financial liberalization after 1988 and second, the FES changed methodology in 2001. Thus, part of the explanation to both papers obtaining different results could lie in the different

\footnotetext{
${ }^{3}$ In particular, taking logs, incorporating observable variables (vector $z$ ), and using a polynomial in age (function $f$ ), Equation 1 becomes $\ln X_{t}=f($ age $)+\gamma^{\prime} z+\ln W+\varepsilon_{t}$. Although the FES is not a panel data set, the long time span makes it possible to take advantage of the cohort variation in the data to estimate a consumption profile for each cohort. By averaging over birth cohort $c$ and estimating it using individual data as opposed to average cohort data, the specification ABHL use is given by: $\ln X_{t}^{c h}=\alpha_{c}+f\left(a g e^{c}\right)+\gamma^{\prime} z_{t}^{c h}+\varepsilon_{t}^{c}+\mu_{t}^{c h}$.
} 
periods considered. By restricting the time span we loose the two oldest cohorts, i.e., those born before 1915.

Step 2 restricts the households in ABHL's sample to those whose head is born between 1940 and 1969, as in CC. Here, we additionally loose the five oldest cohorts (cohorts born between 1915 and 1945) and the two youngest cohorts (cohorts born between 1970 and 1979). More importantly, loosing the oldest cohorts means loosing one of the age categories considered by ABHL (the so-called "old").

Step 3 redefines the age groups in ABHL's. The cut-off age between young and old (or middle aged, according to ABHL categories) becomes 40 as in CC, rather than 35 as in ABHL. Thus, $D Y$ in Equation 2 is redefined to take value 1 for individuals less than 41 years old and zero otherwise, and $D O$ takes value 1 for those individuals older than 40 years old and zero otherwise.

In step 4 we replace the quarterly Government regional house price data used by ABHL with the quarterly Nationwide regional house price data used by $\mathrm{CC}^{4}$. Both ABHL and CC use mix-adjusted house prices, i.e. prices adjusted for the type of dwellings purchased so that the series is more informative than a simple house price average; moreover, CC specifically use an index of house prices with base 1993, quarter 1=100. In 1993 the source of the Government data changed from leading building societies to all mortgage lenders. This change determined a gap between house prices recorded by Nationwide and those recorded by the Government agency and from the early nineties the former are consistently lower in value. Thus, a different measure of house prices might also be part of the explanation as to why the two papers reach different conclusions.

In step 5 we change ABHL's definition of consumption from non-housing consumption to non-durable consumption, as in CC's. Non-housing consumption in ABHL is constructed by adding up all expenditure from FES except expenditure on rents, mortgage payments, local taxes, water charges, and housing repairs and maintenance. We redefine consumption to be non-durable consumption defined as in $\mathrm{CC}$, which is constructed as the sum over the following

\footnotetext{
${ }^{4}$ Both ABHL and CC exclude Northern Ireland and consider 11 Standard Statistical Regions (SSR) labeled as follows: 1 = Northern England $2=$ Yorkshire and the Humbria $3=$ North West England $4=$ East Midlands $5=$ West Midlands $6=$ East Anglia $7=$ Greater London $8=$ South East England (exc. Greater London) $9=$ South West England $10=$ Wales $11=$ Scotland. Both Government and Nationwide data can be freely downloaded from http://www.communities.gov.uk/index.asp?id=1156110 and www.nationwide.co.uk/hpi/regions.htm. Notice that quarterly regional Government data (Table 591 and Table 508) are available only for the new Government Office Regions (GOR) which differ from the old SSR available in FES; moreover, for some of these regions, the relevant series is not available prior 1992 and has to be extrapolated.
} 
expenditure items: food, alcohol, tobacco, fuel, household services, clothing, personal goods and services, public transport, leisure services. The two definitions of consumption are inherently different. Non-housing consumption includes some forms of durable consumption which nondurable consumption does not. The investment aspect of durable goods might make the behavior of durable consumption different from non-durable consumption over the life-cycle. It is also unclear how to assign consumption of durable goods from expenditure data. Differences in the expenditure categories included in each paper can thus certainly account for the different results.

In this step we also move from the IFS version of FES, used by ABHL, to the UK Data Archive public version of FES, used by CC. This change of dataset is necessary because the dataset used by ABHL is extracted from the IFS harmonized version of the FES original raw data and provides a slightly different definition of household income and some expenditure items, which would affect the measure of non durable consumption and the household specific price deflator to be defined below.

In Step 6 we change the price deflator. ABHL use the publicly available national retail price index excluding housing (RPIX) while CC use a household specific price deflator. Because the price deflator affects all the real variables used in the analysis, except for the real interest rate which is deflated using RPI as in CC, it is a potential explanation to the different results obtained in these two papers. We use the household specific price deflator to calculate real consumption, real income, and real house prices. Following CC, the household specific price deflator $p d_{i}$ is a standard Stone price index, computed as a weighted average of the retail price indices corresponding to the expenditure groups, where the weights are the shares of the expenditure groups in the household overall non durable expenditure. In particular, let $e_{s h}$ be household $h$ expenditure for the expenditure group $s$, and $p_{s}$ be the corresponding retail price index; then $p d_{h}$ is computed as follows:

$$
p d_{h}=\sum_{s=1}^{S} \alpha_{s h} \cdot p_{s}
$$

where $S$ is the number of expenditure groups and $\alpha_{s h}=e_{s h} / \sum_{s=1}^{S} e_{s h}$.

In Step 7 we move to a specification that includes age-homeownership interactions, as in CC, but maintains ABHL's specification as in Equation 2. In particular we estimate the following specification: 


$$
\ln X_{t}^{c h}=\alpha_{c}+f\left(a g e^{c}\right)+\gamma^{\prime} z_{t}^{c h}+\theta h_{t}^{r}+\theta_{Y O} h_{t}^{r} D Y O_{t}^{c h}+\theta_{O R} h_{t}^{r} D O R_{t}^{c h}+\theta_{Y R} h_{t}^{r} D Y R_{t}^{c h}+\varepsilon_{t}^{c}+\mu_{t}^{c h}
$$

where as before, superscripts $c h$ denote household $h$ belonging to year-of-birth cohort $c$, and $\mu_{t}^{c h}$ is the household's deviation from the cohort average. The coefficient on house prices for old owners is now given by $\theta$. DYO,DOR, DYR, are dummies that take value 1 for young owners, old renters, and young renters respectively and zero otherwise. Thus the coefficients $\theta_{Y O}, \theta_{O R}$, and $\theta_{Y R}$, represent the additional variation in consumption for each of these groups with respect to the baseline category (old owners). All the other variables are the same as in Equation 2 .

Comparing across age and homeownership simultaneously is important if the relationship between house prices and consumption varies across the ownership spectrum within a given age group. For example, the true effect of house prices on consumption may be positive for old and young owners and negative for old and young renters. Under this scenario the average effect of house prices on consumption by age group is likely to be negligible for both age groups, young and old. Thus, we might be tempted to conclude that house prices have no effect on consumption, and if anything, this effect is the same across age groups. These average effects would however be hiding a differential effect across homeownership status within each age group. ${ }^{5}$

Age and homeownership are however very different variables in nature. An individual can choose whether to buy or not to buy a house, but he or she cannot choose his or her age. CC's paper recognizes this potential limitation and the authors devote much of the paper to deal with it in several ways. ABHL do not interact age and homeownership status but report the results of using homeownership status instead of age group dummies (see Table A2 in the Appendix, specification V in Attanasio, Blow, Hamilton, and Leicester (2009)). The coefficients for owners and renters are very similar in size and slightly higher for renters. CC discuss the endogeneity problem at length in their paper and take care of it by attempting to find out the extent of the bias using simulated household-level data in a model that jointly estimates consumption and the probability of becoming homeowner. CC show that the endogeneity of cohort selection

\footnotetext{
${ }^{5}$ A similar point is made in Hryshko, Luengo-Prado, and Sorensen (2010), who find that the consumption drop upon the arrival of a negative income shock is lower in the presence of house-price appreciation, albeit only for homeowners. These authors interpret these findings as a wealth or collateral effect from increased house prices for owners. They also find that increases in house prices have a positive effect on the consumption of owners and renters in the US, and justify the direct effect of house prices on the consumption of renters as being the result of house prices being correlated with income or expectations of future income.
} 
essentially affects the coefficients of old vs young homeowners but does not change the result that homeowners consume more out of house price increase than renters. The coefficient for young homeowners is highest in this case and CC justify it on the basis of credit constraints. To the extent that CC's analysis and main findings stem from and provide strong support for their paper's benchmark specification used in our comparison exercise, it is still a very valuable exercise to look at the robustness of this rather parsimonious specification. We discuss the endogeneity problem in more detail Section 4, but do not expand on these endogeneity issues for purposes beyond of this comparison exercise.

In steps 8-10 we gradually change ABHL's empirical specification to make it closer to that of CC. In step 8 we change the list of covariates $z_{t}^{c h}$ included in the analysis. In particular we estimate Equation 4 by including the real household income as an additional control, calculated as gross current income of the head plus gross current income of wife as in CC. The inclusion of real income in ABHL's consumption equation simply serves to approach the Euler equation specification. Real income growth may be present in the Euler equation to approximate the variance (and possible higher order moments) of consumption growth (e.g., Carroll 2001), which enters the log linear Euler equation when the approximation used is a second order Taylor expansion (e.g., Ludvigson and Paxson 2001). ${ }^{6}$ In contrast, the level of real income should not be an explanatory variable in the reduced form of the life-cycle equation used in ABHL, as the deterministic part of the income is already captured by the constant term and the innovations to permanent income as well as transitory shocks to current income are part of the residuals (e.g., Attanasio, Blow, Hamilton, and Leicester 2009). We also include the real interest rate and compute it, as in CC, on the basis of the Bank of England base nominal interest and of the expost RPI inflation ${ }^{7}$. We also exclude demographic and socio-economic characteristics as controls (number of children in the household, number of adults, a dummy for the presence of two or more adults, education dummies, occupation dummies, a polynomial of age up to the power of five, region dummies, and monthly dummies). These covariates are an essential part of the reduced form life-cycle model but not of the Euler equation model. Instead, following CC's specification, we include the log of household size, a quadratic function of age and quarter (as opposed to

\footnotetext{
${ }^{6}$ There are other efforts to account for income expectations. For example Disney, Gathergood, and Henley (2010)use subjective expectations to the overall financial situation of the household in the following year to control for income expectations and identify unanticipated house price shocks from an estimated house price process.

${ }^{7} \mathrm{RPI}$ is the quarterly retail price index. Results are not substantially different if inflation is computed using the quarterly retail price index excluding housing
} 
monthly) dummies. Except for house prices, which are quarterly, FES data are monthly and this time unit is maintained throughout the various level specifications. The time structure is changed to quarterly when moving to synthetic panel. We also use birth-homeownership cohort dummies as opposed to birth cohort dummies.

In step 9 we move one step closer to CC by estimating Equation 4 on synthetic cohort data such that:

$$
\ln X_{i, t}=\alpha_{i}+\gamma^{\prime} z_{i, t}+\theta h_{t}^{r}+\theta_{Y O} h_{t}^{r} D Y O_{i, t}+\theta_{O R} h_{t}^{r} D O R_{i, t}+\theta_{Y R} h_{t}^{r} D Y R_{i, t}+\varepsilon_{i, t}
$$

where the subscript $i$ denotes year-of-birth $\mathrm{x}$ homeownership cohort and subscript $t$ now refers to year-quarters as opposed to year-months. The construction of cohorts on the basis of age-homeownership used by CC may be problematic because of the endogeneity of the homeownership status. This endogenous selection implies that synthetic cohorts constructed this way are not a random draw of the population survey which may lead to biased estimators. Additionally, if the number of observations in the synthetic panel cells related to homeowners is small, this may create sampling noise (e.g., Browning, Deaton, and Irish 1985, Deaton 1985). We explore these two options separately in the next section.

In step 10 we change the functional form (an Euler equation estimated by a GLS randomeffects model with $\mathrm{AR}(1)$ disturbances as in $\mathrm{CC}$ rather than a reduced form life-cycle model estimated in levels as a pooled OLS regression as in ABHL in Equation 5). CC's baseline regression consists of regressing changes (as opposed to levels) in consumption on changes in house prices. In particular, they estimate the following Euler equation, which is based on the Euler equation they outline in page 600 (Campbell and Cocco (2007), Equation 1):

$$
\begin{aligned}
\Delta c_{i, t}= & \alpha_{i}+\beta_{1} r_{t}+\beta_{2} \Delta y_{i, t}+\theta \Delta h_{t}^{r}+ \\
& \theta_{Y O} \Delta h_{t}^{r} D Y O_{i}+\theta_{O R} \Delta h_{t}^{r} D O R_{i}+\theta_{Y R} \Delta h_{t}^{r} D Y R_{i}+ \\
& \beta_{3} \Delta z_{i, t}+\beta_{4}^{\prime} q+\varepsilon_{i, t}
\end{aligned}
$$

where the subscripts are defined as in Equation $5, r_{t}$ is the log real interest rate, $\Delta c_{i, t}=$ $\ln c_{i, t}-\ln c_{i, t-1}$ is real non-durable consumption growth, $\Delta y_{i, t}=\ln y_{i, t}-\ln y_{i, t-1}$ is real income 
growth, $\Delta h_{i, t}^{r}=\ln h_{i, t}^{r}-\ln h_{i, t-1}^{r}$ is real house price growth, $z_{i, t}$ is a vector of cohort characteristics which includes demographic variables as described in Step 8 and $q$ is a vector of quarter dummies.

\section{Empirical Results}

Column ABHL reproduces ABHL's results. Although the level of house prices explains consumption over the life-cycle, the coefficients are remarkably similar for the three age groups considered. The elasticity of non-housing consumption to house prices is $0.16 \%$ for all groups, and the differences are not statistically significant at standard levels. ABHL's results are thus inconsistent with the wealth hypothesis and the authors conclude by saying that "on average over the past twenty-five years, these [collateral and wealth channel] effects have been smaller than the common causality channel" (see page 43, second paragraph in Attanasio, Blow, Hamilton, and Leicester (2009)).

Column 1 shows the results from changing the time period from 1978 until 2001 as in ABHL to 1988 until 2000 as in CC. Sample sizes decrease from 149,484 observations to 77,723 observations. Results however do not significantly change from ABHL's results presented in the previous column, and thus continue to support the common factor hypothesis.

The specification in Column 2 drops cohorts born before 1940 and after 1969 from the sample as in CC. We loose the five oldest cohorts and the two youngest cohorts, which reduces the number of observations from 77,723 to 47,206. The magnitude of the coefficients for the young and middle aged (the remaining groups) remains virtually identical to that in Column $A B H L$ up to two decimal points, and thus continue to lend support to the common factor hypothesis.

The specification in Column 3 redefines age groups according to CC's specification, where old households are considered to be those with household heads over 40 years old, and young households are those with household heads of 40 years old or less. The number of observations remains intact with respect to the previous specification. The house price coefficients remain virtually unchanged.

The specification in Column 4 uses the index of nominal house price data used by CC instead of the Government house price data. Figure 1 shows that the underlying house price data is different between the two papers, the Nationwide series used by CC being lower than the Government series used by ABHL. Time series plots of the regional prices show that the 


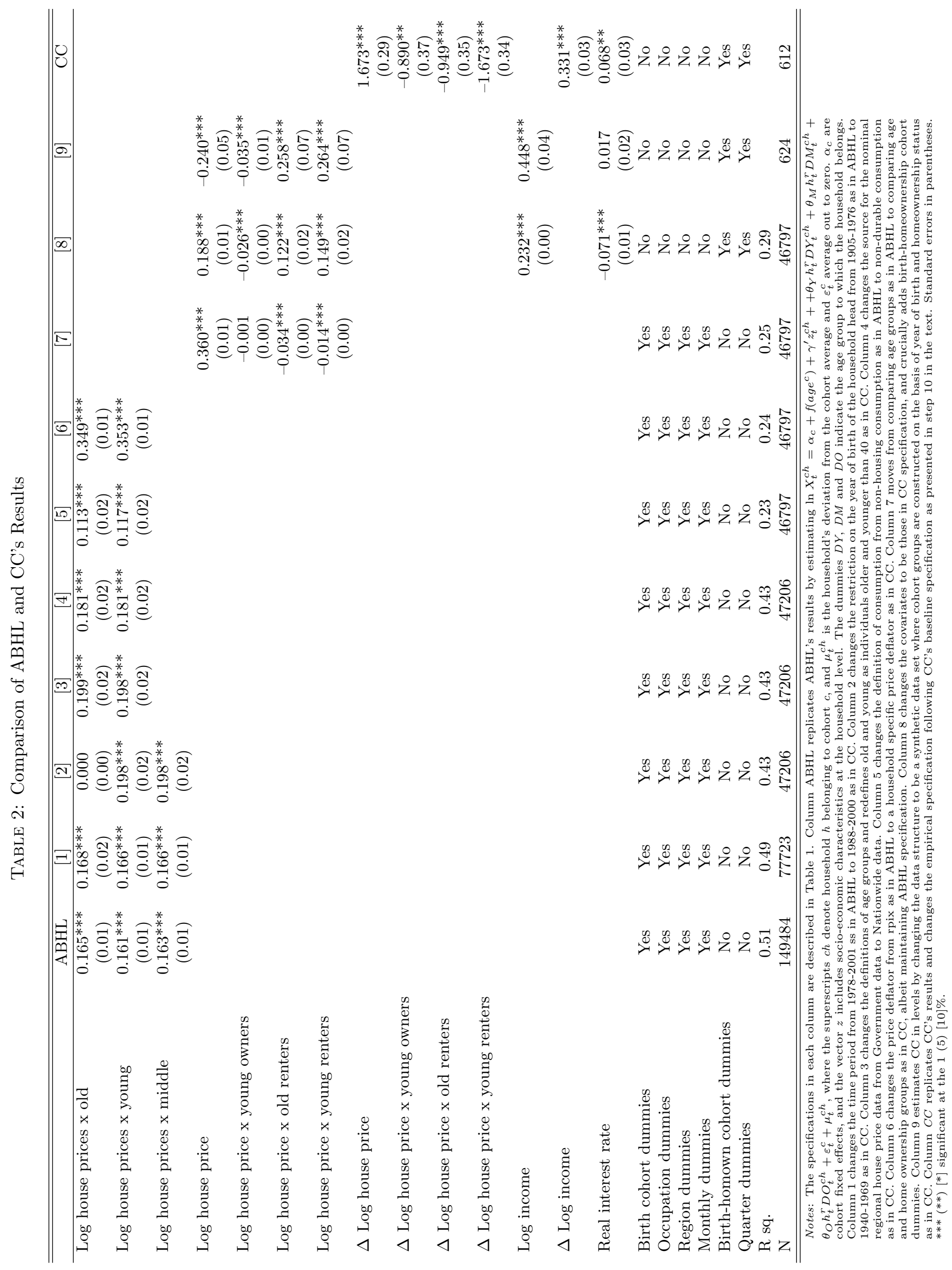


Figure 1: Time series of house price data

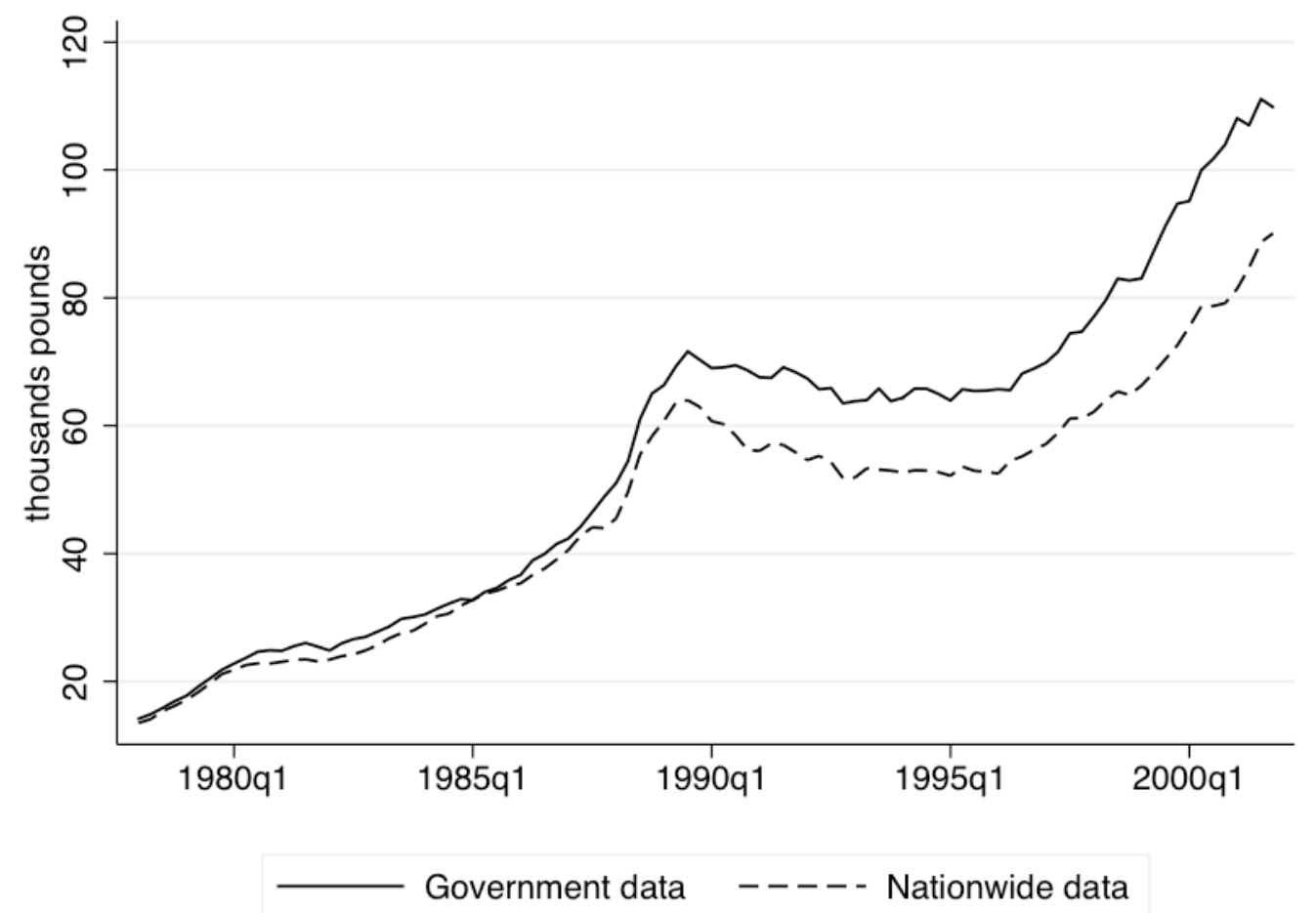

difference between the two series starts from the early nineties, in conjunction with the change in the source of the Government data. The coefficients of interest presented in Column 4 experience a statistically significant drop with respect to the coefficients in the previous specification, and move from .199 and .198 to .181 for both old and young. Nonetheless, in contrast to what the wealth hypothesis would predict, the house price coefficients are of the same magnitude and not statistically significantly different between the two age groups at standard significance levels. ${ }^{8}$

The specification in Column 5 changes the definition of consumption from non-housing to non-durable consumption. The number of observations decreases slightly due to the change in the data source, from the IFS version of the FES used by ABHL to the UK Data Archive version of the FES used by CC. Figure 2 depicts the kernel density functions of the two definitions of consumption. The distributions are indeed very similar, resulting in little changes in the coefficients with respect to the previous specification. The coefficients on non-durable consumption drops further from .181 in Column 4 to .113 and .117 for old and young respectively. However,

\footnotetext{
${ }^{8}$ We cannot reject the null hypothesis of equality between the coefficients of the young and the old: $\mathrm{F}(1,47156)$ $=0.03$. Prob $>\mathrm{F}=0.8697$.
} 
Figure 2: Distributions of alternative definitions of non-durable consumption

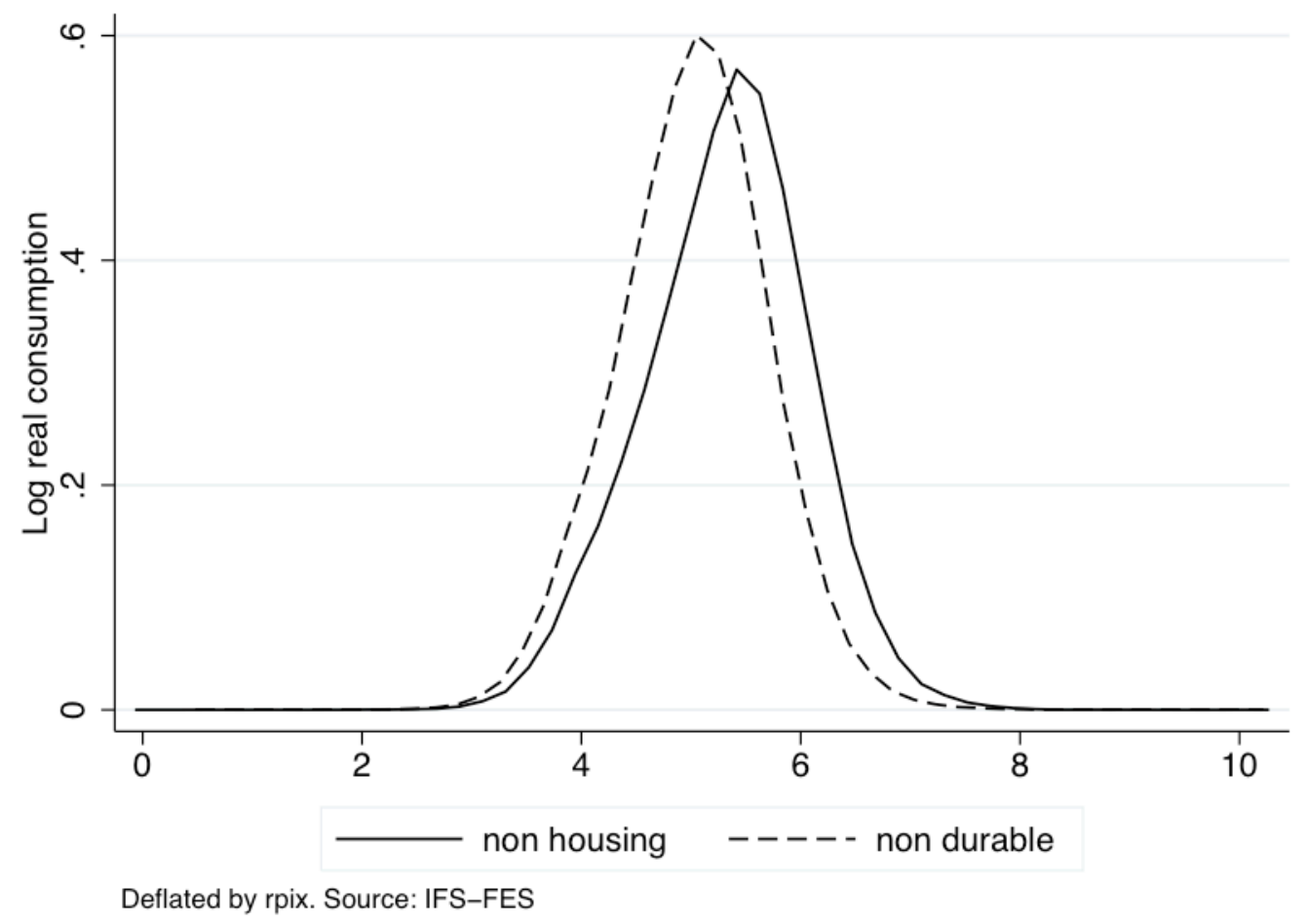

we still cannot reject the null that the coefficients of old and young are statistically equal to each other at standard significance levels, providing no support for the wealth hypothesis. ${ }^{9}$

In Column 6 we use CC's household price deflator, rather than ABHL's RPIX, to convert nominal values of consumption and income to real values. The first panel in Figure 3 shows the densities of both price deflators: the household specific price deflator is smoother and has a greater variance than the rpix index. ${ }^{10}$ The other panels in Figure 3 compare the densities of the real variables of interest (i.e., consumption, income, and house prices) when using the household specific price deflator as in $\mathrm{CC}$ and the retail price deflator as in ABHL (either the monthly rpix for consumption and income or the quarterly rpixq for house prices). The underlying nominal variables are the same in both cases. Real log consumption and real log income are remarkably

\footnotetext{
${ }^{9}$ We cannot reject the null hypothesis of equality between the house price coefficient of the young and the old: $\mathrm{F}(1,46747)=1.81$. Prob $>\mathrm{F}=0.1784$. The coefficients of interest are slightly higher when using IFS-FES data and the closest definition of non durable consumption: 0.136 for old and 0.139 for young. The null of equality cannot be rejected at usual statistical levels.

${ }^{10}$ Notice that ABHL distinguish "food" expenditure into "food in "and "food out", whereas CC use the item "food" which is close to but not precisely equal to the sum of "food in" and "food out". The prices of "food in" and "food out" obtained from the IFS version of the FES data, which are needed to construct the household specific price deflator, are very different from each other and it turns out that the price of "food in" is the same as the price of "food" used by CC and obtained from Office of National Statistics.
} 
FIGURE 3: Kernel density distributions of real variables with alternative price deflators
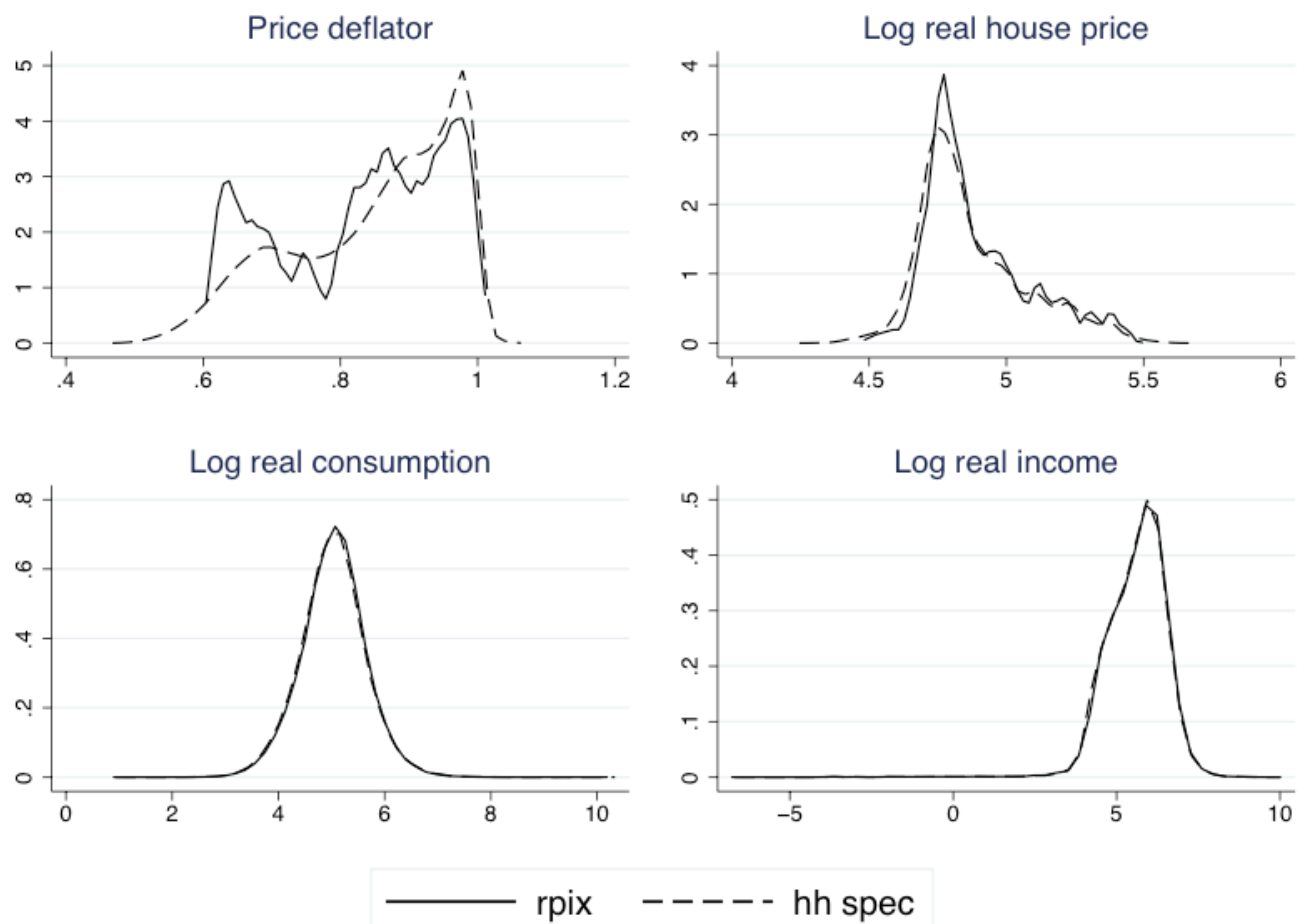

hh spec

Note: "rpix" is the national retail price index excluding housing; "hh spec" is the household specific price deflator computed according to Equation 3.

similar when using each of the price deflator, except for the tails. Real log of house prices is also similar, although there is more variation than with real log consumption and real log income.

The coefficients on non-durable consumption increase significantly to 0.427 and 0.430 for old and young respectively, but are still far from the magnitude of CC's estimates presented in Column $C C$ of Table 2. These coefficients continue to lend support to the common factor hypothesis as they are not statistically different from each other. From here onwards we also adjust the tails of log real non-durable consumption and log real income as done by CC. Specifically, values which fall below $5 \%$ or beyond $95 \%$ of the distribution are given the values of the 95th and the 5th percentile respectively. The tail distribution correction implies a drop of the coefficients of interest to .353 (for young) and .349 (for old), but as before the two coefficients are not statistically different at standard significance levels. ${ }^{11}$

The specification in Column 7 introduces the age-homeownership groups as in CC, as op-

\footnotetext{
${ }^{11}$ The null of equality cannot be rejected: $\mathrm{F}(1,46747)=2.06$. Prob $>\mathrm{F}=0.1509$
} 
posed to the age groups used in ABHL's main specification. As in CC, in this specification the estimated coefficient on house prices measures the effects of house price changes on the consumption of old homeowners, and the estimated coefficients on the interaction variables measure the additional effects of house prices for the particular groups defined by the dummy variables. We find statistically significant heterogeneity in the consumption effects of house prices across the different groups, however these differences do not appear to be economically very big. The estimated coefficient on house prices is highest for old homeowners - though still much lower in magnitude than the corresponding coefficient estimated by CC (0.360 vs 1.673$)$. The effects of house prices on consumption are lower for renters than for old homeowners. The coefficients of house price interacted with the renter dummies are negative and significant for both old $(-0.034)$ and young (-0.014) renters. However, unlike the wealth hypothesis would predict, the elasticities for both groups remain positive and statistically different from zero. ${ }^{12}$ In contrast to CC who find that young homeowners' consumption is less sensitive to house prices than old homeowners' consumption, we fail to find any difference between the elasticities of consumption to house prices for these two groups.

The specification in Column 8 replaces ABHL's covariates to those use in CC's specification and uses birth-homeownership cohort dummies instead of year of birth cohort dummies to bring ABHL's household-level specification closer to that of CC. At this stage any confirmation of the common factor hypothesis fades away. Table A-1 in the Appendix shows the intermediate steps. Although the change of the list of covariates does not qualitative change results with respect to Column 7, using year of birth-homeownership dummies raises the coefficients of renters by 10 percentage points or more while reducing the coefficient of old homeowners. On the whole, renters (young renters in particular) show the highest sensitivity of consumption to house prices and young owners show the least. Despite of the fact that the introduction of birthhomeownership cohort dummies takes the specification closer to CC's, the wealth hypothesis is plainly rejected.

The specification in Column 9 is the same as that in Column 8 but estimated on syntheticlevel data instead of household-level data. In that way, it is a closer fit to CC in levels. Under this specification owners' consumption, old and young, not only has the lowest sensitivity to

\footnotetext{
${ }^{12} \mathrm{CC}$ also find a positive elasticity of consumption for old renters and justify it by claiming that house prices may, to some extent, proxy for aggregate economic conditions. However, with regard to young renters, CC find a coefficient that is not significantly different from zero whereas in our case the coefficient is statistically different from zero and its size is close to that estimated for old homeowners.
} 
house prices, but the house prices coefficients are also negative for these groups. In contrast, renters' consumption exhibit a sensitivity to house prices that is close to zero. Additionally, although we find differences in the sensitivity of consumption to house prices between old and young, we fail to see any differences between owners and renters within those groups. These results are plainly contrary to what the wealth hypothesis would predict. They are also not consistent with the common factor hypothesis, as we would expect no big differences among the four groups.

The specification in Column CC presents the results from changing the empirical specification to get exactly CC's results (up to the third decimal point), so that quoting CC: "In fact, the magnitude of the estimated coefficients tells us that the effects of house price changes on consumption are lowest for young renters, followed by old renters and young homeowners." (see page 603, third paragraph in Campbell and Cocco (2007)). As in Column 7, the consumption of old owners shows the highest (positive) sensitivity to house prices (1.673). This elasticity of consumption for old homeowners is however more than four times greater than the size found in the previous specification. The coefficients for the rest of the groups are not only different from the coefficients found in Column 7 but also compare differently against each other so that the wealth hypothesis is now supported. The groups in the middle (young home owners and old renters) have an elasticity of 0.783 and 0.724 respectively (the differences between these two groups are not statistically significant however). Young renters' consumption exhibits no sensitivity at all, which is not entirely consistent with the wealth hypothesis as CC recognize: "The small effect of house prices on the consumption of young renters is puzzling since a wealth effect should lead these households to cut consumption when house prices increase..." (see page 605, second paragraph in Campbell and Cocco (2007)).

We also compute the MPC to check if these large differences in the estimated elasticities also imply large differences in the marginal propensities to consume. In particular, we compare the MPC derived from the estimated elasticities of old households shown in Columns ABHL, $\mathrm{CC}$ and in Column 8 of Table 2, which is our intermediate specification. We compute the MPC for the year 2000, which is the base year of the household specific price deflator, so that nominal and real values are the same. We obtain the yearly expenditure on non-durables for old households from their FES weekly equivalent expenditure and we compute, from Nationwide data, the average value of a house in Britain in the last quarter of 2000 as the mean of the house 
values in the same year in the 11 regions considered in both papers. The yearly expenditure on non durables is 15,392 pounds and the average house value is 79,155 pounds. Then, the MPC are, respectively, 0.032 for ABHL household-level specification, 0.036 for the intermediate level-specification, and 0.325 for CC specification. These imply that a one pound rise in the value of the house, increases consumption of old homeowners by $3.2,3.6$ and 32.5 pence in the three cases, respectively. The country average MPC out of housing wealth estimated by De Bonis and Silvestrini (2012) for the period 1997-2008, using cross-country panel data, are in the range of 0.5 cents to 2.4 cents per additional euro (De Bonis and Silvestrini (2012) Table A-10). For the UK, the estimated MPC for the same period is 6.7 cents per additional euro (De Bonis and Silvestrini (2012) Table A-8). Thus, the MPC value that derives from CC's specification in Column CC is an order of magnitude larger than those estimated in the alternative cases and in the literature. ${ }^{13}$

In conclusion, by moving from Column 1 to Column 7 in Table 2 we rule out a number of potential reasons related to the basic data construction. In particular, we show that ABHL's results are robust to changes in the sample period, changes in the definition of consumption, and changes in the price data source and FES version used. Moreover, although the magnitude of ABHL's coefficients is sensitive to the use of the deflator, the qualitative implications remain unchanged. In the steps moving from Column 7 to Column CC, ABHL's results generally break down. However, the wealth hypothesis is not confirmed in any of the intermediate specifications either. ABHL's results seem to be particularly vulnerable to the inclusion of homeownership in the analysis (although It is difficult to draw any conclusions from this last observations given that homeownership is endogenous), and CC's support for the wealth hypothesis is only found in one specification. The MPC figures implied by ABHL's specification lie closer to those reported in the literature.

\footnotetext{
${ }^{13} \mathrm{MPC}$ reported in the literature do not refer to age groups. Notice also that the MPC we compute using CC elasticity (0.325), contrasts with the lower value (0.08) reported by $\mathrm{CC}$ and obtained from an elasticity of 1.22 (pag.601). We believe the MPC in CC (pag.601-602) is, in fact, double of what is stated. CC report a yearly expenditure on non durables of 5,200 (and average house value 81,628). However, all monetary values in FES are weekly equivalent (for 2000-2001 see the following manuals: Family Expenditure Survey (2001b), pag.1 and Family Expenditure Survey (2001a), explanatory note 5), and thus yearly expenditure on non durables should be $200 * 52=10,400$ pounds as opposed to 5,200 pounds, reported in CC.
} 


\section{Data Structure versus Functional Forms}

In this section we focus on the steps from Column 7 to Column CC in Table 2 and try to shed some new light on what is driving the results between the two papers by attempting to disentangle the role of the data structure from the role of the functional form. The transition from Column 7 to Column $\mathrm{CC}$ in Table 2 involves a few important changes. In particular, it involves a comparison across year of birth-homeownership groups as in CC, rather than across year of birth groups as in ABHL (Column 7 to Column 8). It also entails the aggregation of data from household level to a synthetic panel (Column 8 to Column 9), and it involves changing the functional form from a level specification as in ABHL, to an Euler equation specification as in CC (Column 9 to Column CC). One complication in comparing the results from Column 8 onwards is the fact that whereas age is exogenous, being a homeowner or not is a choice. The underlying population of homeowners is thus not a random draw of the overall population, which may bias not only the coefficients in a household level estimation but also the coefficients in a synthetic cohort estimation.

For the purpose of this comparison exercise, we net this endogeneity problem out by constructing household groups according to the year of birth dimension only. Our strategy is two-fold. First, we maintain the functional form constant (levels specification as in ABHL) and compare the role of the different data structures (household-level vs synthetic cohort-level) within a given specification. This step allows us to gauge the extent to which the data structure can explain the differences in the results in the two papers. In particular, this step involves estimating a level specification as in ABHL (Equation 4 in Step 8) using household level data, and comparing it to the same estimation using year-of-birth synthetic cohorts (as in Equation 5 in Step 9). The only difference with the specifications in Table 2 is that synthetic cohorts are constructed on the basis of year of birth only, and not year of birth and homeownership status. The lack of panel data prevents us from being able to estimate CC specification on household level data, thus from comparing the same specification estimated on synthetic panel data.

Second, we assess the role of the functional form by keeping the data structure constant (synthetic cohorts constructed on the basis of year of birth) and comparing across estimation methods (levels as in Equation 5 in Step 9 vs Euler equation as in Equation 6 in Step 10). Notice that in doing so we additionally tackle the problem of sampling noise due to small cell

sizes mentioned before, since synthetic cohorts constructed on the bases of age are bigger in 
this case (the structure of the synthetic panel reported in Table 3 shows that the number of observations in the cells related to homeowners is small (e.g., Deaton 1985). As in our first step, the cross sectional nature of the data means that this comparison can only be made when the structure of the data is in the form of synthetic cohorts.

TABle 3: Synthetic Cohort Panel Structure

\begin{tabular}{|c|c|c|c|c|c|c|c|}
\hline \multirow[b]{2}{*}{ year of birth } & \multirow[b]{2}{*}{ homeowner } & \multicolumn{3}{|c|}{ ABHL:IFS-FES } & \multicolumn{3}{|c|}{ CC:Archive FES } \\
\hline & & min cell & max cell & ave cell & min cell & max cell & ave cell \\
\hline $1940-44$ & 0 & 21 & 44 & 31.2 & 18 & 54 & 29.4 \\
\hline $1945-49$ & 0 & 22 & 48 & 34.4 & 19 & 56 & 33.0 \\
\hline $1950-54$ & 0 & 23 & 52 & 38.6 & 23 & 51 & 36.7 \\
\hline $1955-59$ & 0 & 26 & 62 & 46.5 & 22 & 75 & 44.7 \\
\hline $1960-64$ & 0 & 35 & 80 & 58.6 & 29 & 104 & 57.4 \\
\hline $1965-69$ & 0 & 33 & 81 & 61.4 & 25 & 118 & 59.9 \\
\hline $1940-44$ & 1 & 69 & 131 & 99.5 & 69 & 166 & 101.1 \\
\hline $1945-49$ & 1 & 95 & 169 & 127.7 & 95 & 209 & 129.9 \\
\hline $1950-54$ & 1 & 87 & 143 & 116.5 & 84 & 185 & 118.1 \\
\hline $1955-59$ & 1 & 87 & 144 & 119.4 & 91 & 192 & 121.4 \\
\hline $1960-64$ & 1 & 83 & 140 & 115.5 & 84 & 226 & 118.7 \\
\hline $1965-69$ & 1 & 12 & 119 & 86.7 & 12 & 206 & 90.0 \\
\hline
\end{tabular}

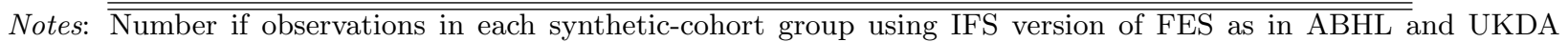
version of FES as in CC.

Results are presented Table 4. Column 1 reproduces the results in Column 6 of Table 2 for comparison and continuation purposes. Columns 2 and 3 in Table 4 shows the results from keeping the empirical specification in levels. We see that the qualitative results are the same as those presented in Column 6, in that coefficients of old and young are not statistically different from each other. In contrast, the coefficients from estimating on synthetic level data the specification in levels in Column 3 and the Euler equation specification in Column 4 are very different from each other. Additionally, whereas the level estimation in Column 3 is consistent with the common factor hypothesis, the Euler equation estimation in Column 4 is consistent with the wealth hypothesis. This result is analogous to those in Browning, Deaton, and Irish (1985) and Deaton (1985), and suggests that the year to year changes within cohorts captured by the Euler equation specification used by CC, differs from the life cycle variation across cohorts captured by the levels specification used by ABHL.

There are several interesting points to draw from the results presented in Table 4. First, although the comparison of Columns 2 and 3 yield similar qualitative results in support of the common factor hypothesis, the fact that the coefficients estimated using household level data differ consistently from those estimated using synthetic cohort data, also indicates that the 
year-quarter-birth cohort dummies are likely to be weak instruments, at least for some of the explanatory variables in the household level regression. ${ }^{14}$ Second, when using an Euler equation specification the house price coefficients associated to old and young households are statistically and economically different from each other regardless of the construction of synthetic cohorts, yielding support to the wealth hypothesis. Old households present a statistically significant elasticity of consumption to house prices of 1.34. In contrast, the elasticity of young households is much lower in magnitude $(0.21)$ and not statistically significant. ${ }^{15}$

The results presented in this Section suggest that the different specification in the two papers, and not necessarily the data structure, is the main factor explaining the different results. The Euler equation and the reduced form life-cycle model stem from the same permanent income hypothesis, according to which agents maximize their life time utility conditional on current resources and the information on the evolution of incomes and interest rates. However, both approaches are approximations. The Euler equation estimated by $\mathrm{CC}$ is the standard log linearized first order condition of the intertemporal utility maximization derived on the assumption of an iso-elastic and additively separable utility function. Hence it is not a consumption function but an equilibrium condition. Empirical consumption Euler equations have long been criticized for taking a linear short cut which produces significant approximation biases (e.g., Carroll 2001, Ludvigson and Paxson 2001), except in a few cases (e.g., Attanasio and Low 2004). By contrast, the reduced form equation estimated by ABHL is a consumption function that accords with a simple life-cycle model, in that households are assumed to consume, in each period, a fraction of their lifetime wealth. Thus the opposite results may relate to the different ways to approximate the consumption function when a closed form solution is not possible (a closed form solution is possible only for very special and unrealistic preferences, ruling out for example the largely used iso-elastic utility functions).

\footnotetext{
${ }^{14}$ The estimation of Equation 5 in Step 9 on year of birth synthetic cohort data is equivalent to the 2SLS estimation of Equation 4 in Step 8 using household level data, where the explanatory variables: $a g e, a g e^{2}$, famsize, Log income, real interest rate, Log house price, Log house price x DY, are instrumented using yearquarter-birth cohort dummies.(e.g., Veerbek 2008). Regarding the validity of instruments, the Sargan test of overidentifying restrictions is rejected (score $X^{2}(297)=1110.48$ with a $\mathrm{p}$ value of 0.00 ); the Shea's partial Rsquared are particularly low for famsize and for Log income for which the $\mathrm{F}$ tests on the first stage are also relatively low (12.08 and 9.16, respectively). Results are available on request.

${ }^{15}$ Although results based on the Euler equation change somewhat once a slight oversight in CC's code is amended (as explained in Appendix B), the wealth hypothesis still finds support. In contrast, results based on the life-cycle model do not change substantially when correcting for the error, probably because the error magnifies in first differences.
} 
TABLE 4: Comparison of ABHL and CC's results along the age dimension

\begin{tabular}{|c|c|c|c|c|}
\hline & \multirow[b]{2}{*}{ [1] } & \multicolumn{3}{|c|}{ Year-of-birth cohorts } \\
\hline & & {$[2]$} & {$[3]$} & {$[4]$} \\
\hline Log house price $\mathrm{x}$ old & $\begin{array}{c}0.349^{* * * *} \\
(0.01)\end{array}$ & $\begin{array}{c}0.216^{* * *} \\
(0.01)\end{array}$ & & \\
\hline Log house price $\mathrm{x}$ young & $\begin{array}{c}0.353^{* * *} \\
(0.01)\end{array}$ & $\begin{array}{c}0.203^{* * *} * \\
(0.01)\end{array}$ & & \\
\hline Log house price $\mathrm{x}$ old & & & $\begin{array}{c}-0.133^{* * *} \\
(0.04)\end{array}$ & \\
\hline Log house price $\mathrm{x}$ young & & & $\begin{array}{c}-0.150^{* * *} \\
(0.04)\end{array}$ & \\
\hline$\Delta$ Log house price $\mathrm{x}$ old & & & & $\begin{array}{c}1.340^{* * *} \\
(0.24)\end{array}$ \\
\hline$\Delta$ Log house price $\mathrm{x}$ young & & & & $\begin{array}{c}0.207 \\
(0.20)\end{array}$ \\
\hline Log income & & $\begin{array}{c}0.248^{* * *} \\
(0.00)\end{array}$ & $\begin{array}{c}0.427^{* * *} \\
(0.04)\end{array}$ & \\
\hline$\Delta \log$ income & & & & $\begin{array}{c}0.486 * * * \\
(0.04)\end{array}$ \\
\hline real interest rate & & $\begin{array}{c}-0.071^{* * *} \\
(0.01)\end{array}$ & $\begin{array}{l}0.006 \\
(0.02)\end{array}$ & $\begin{array}{c}0.074^{* *} \\
(0.03)\end{array}$ \\
\hline Birth cohort dummies & Yes & Yes & Yes & Yes \\
\hline Occupation dummies & Yes & No & No & No \\
\hline Region dummies & Yes & No & No & No \\
\hline Monthly dummies_ & Yes & No & No & No \\
\hline Quarter dummies & No & Yes & Yes & Yes \\
\hline R sq. & 0.24 & 0.28 & & \\
\hline $\mathrm{N}$ & 46797 & 46798 & 312 & 312 \\
\hline
\end{tabular}




\section{Conclusion}

This paper revisits the debate about the presence of wealth effects associated to house price changes. To that end, we compare the results from two influential papers which, although posing a common research question, find conflicting evidence about the consumption response of U.K. households to movements in house prices. These papers use the same data set, the UK Family Expenditure Survey, but estimate different consumption function over different sample periods using different measures of consumption. According to Campbell and Cocco (2007) older households increase their consumption in response to a rise in house prices. They interpret these responses as evidence of a wealth effect in consumption. Attanasio, Blow, Hamilton, and Leicester (2009) reach the opposite conclusion. This paper controls for the differences in the estimated consumption functions and the data structure to determine the causes of the disparity in the estimates of the response of U.K. household consumption to changes in house prices.

Support for the common factor hypothesis is found throughout specifications where a lifecycle model of consumption is estimated using household level data. Results are robust to changes in the sample period, changes in the definition of consumption, and changes in the data source (both, price data and expenditure data). Furthermore, although the magnitude of the house price coefficients is sensitive to the type of price deflator used, the qualitative implications remain unchanged. In contrast, the wealth hypothesis finds some support only when an Euler equation specification is estimated with synthetic-cohort level data. We rule out that the results from estimating an Euler equation with synthetic-cohort level data are being driven by the problems generated by the construction of synthetic cohorts on the basis of an endogenous variable, such as home ownership status. We also rule out that these results are being driven by the sampling noise due to small sample sizes in some of the synthetic cohorts groups.

Our comparison exercise draws attention to the need for further research on the virtues and limitations of Euler equations and on consumption functions in general. By comparing results across specifications - while keeping the data structure constant in year of birth synthetic cohorts- we show that the crucial element driving the different results between the two papers is the estimation of a life-cycle model of consumption as opposed to estimating an Euler equation model. It is not possible to get a deeper understanding of the relative importance of the aggregation and the functional form for the results using this (cross sectional) data set. In particular 
we cannot rule out that the results from estimating the Euler equation on panel data would give the same results as the level specification. An alternative would be to use numerical methods and simulations (e.g. Attanasio and Weber 2010). We leave this avenue for further research. 


\section{References}

Attanasio, O. P., L. Blow, R. Hamilton, and A. Leicester (2009): "Booms and Busts: Consumption, House Prices and Expectations," Economica, 76(301), 20-50.

Attanasio, O. P., And H. Low (2004): "Estimating Euler Equations," Review of Economic Dynamics, 7, 406-435.

Attanasio, O. P., and G. Weber (1994): "The UK Consumption Boom of the Late 1980s: Aggregate Implications of Microeconomic Evidence," The Economic Journal, 104, 1269-1302.

(2010): "Consumption and Saving: Models of Intertemporal Allocation and Their Implications for Public Policy," Journal of Economic Literature, 48, 693-751.

Banks, J., And S. Tanner (2002): "Household portfolios in the United Kingdom," in Household Portfolios, ed. by L. Guiso, M. Haliassos, and T. Jappelli, chap. 6. MIT Press, Cambridge.

Browning, M., M. Gortz, and S. Leth-Petersen (2011): "Housing Wealth and Consumption: A Micro Panel Stud," Cam working papers, University of Copenhagen. Department of Economics. Centre for Applied Microeconometrics.

Browning, M. J., A. S. Deaton, and M. Irish (1985): "A profitable approach to labor supply and commodity demands over the life-cycle," Econometrica, 53.

Campbell, J. Y., And J. F. Cocco (2007): "How do house prices affect consumption? Evidence from micro data," Journal of Monetary Economics, 54, 591-621.

Carroll, C. D. (2001): "Death to the Log-Linearized Consumption Euler Equation! (And Very Poor Health to the Second-Order Approximation)," Advances in Macroeconomics, 1.

Case, K., R. Quigley, And J. Shiller (2001): "Comparing Weatlth Effects: The Stock Market vs. the Housing Market," NBER Working Paper Series, Vol. w8606.

De Bonis, R., And A. Silvestrini (2012): "The effects of financial and real wealth on consumption: new evidence from OECD countries," Applied Financial Economics, 22(4), 409425.

Deaton, A. (1985): "Panel data from a time-series of cross-sections," Journal of Econometrics, 30.

Dewald, W. G., J. G. Thursby, and R. G. Anderson (1986): "Replication in Empirical Economics: The Journal of Money, Credit and Banking Project," The American Economic Review, 76, 587-603.

Disney, R., J. Gathergood, and A. Henley (2010): "House Price Shocks, Negative Equity, and Household Consumption in the United Kingdom," Journal of the European Economic Association, 8(6), 1179-1207.

Family Expenditure Survey (2001a): "Specification of product codes," Derived database, 3. (2001b): "The structure of the 2000-2001 database," User Guide, 1.

Hamermesh, D. S. (2007): "Replication in Economics," NBER WP 13206. 
Hryshko, D., M. J. Luengo-Prado, and B. E. Sorensen (2010): "House prices and risk sharing," Journal of Monetary Economics, 57(8), 975-987.

Kiyotaki, N., A. Michaelides, and K. Nikolov (2011): "Winners and Losers in Housing Markets," Journal of Money, Credit and Banking, 43(2-3), 255-296.

Leth-Petersen, S. (2010): "Intertemporal Consumption and Credit Constraints: Does Total Expenditure Respond to an Exogenous Shock to Credit?," American Economic Review, 100(3), 1080-1103.

Ludvigson, S., And C. H. PAxson (2001): "Approximation Bias in Linearized Euler Equations," The Review of Economics and Statistics, 83(2), pp. 242-256.

Ludwig, A., And T. Slok (2004): "The Relationship between Stock Prices, House Prices and Consumption in OECD Countries," Topics in Macroeconomics, 4.

Muellbauer, J., And A. Murphy (1990): "Is the UK balance of payments sustainable?," Economic Policy, (11), 345-83.

ONS (2009): "Wealth in Great Britain: main results from the wealth and assets survey 2006/08," Discussion paper, ONS.

Veerbek, M. (2008): "Pseudo Panels and Repeated Cross Sections," in The Econometrics of Panel Data. Fundamental and Recent Development in Theory and Practice, ed. by M. Lászlo, and P. Sevestre, vol. 49 of Advanced Studies in Theoretical and Applied Econometrics, chap. 10. Springer, Netherlands, 3rd edn. 


\section{Appendix A: Intermediate Steps}

Table A-1 presents the intermediate steps necessary to move from the life-cycle specification presented in Column 7 in Table 2 to CC's baseline results in Column $C C$ in Table 2. For ease of reading, Column 1 and Column 8 of Table A-1 reproduce Column 7 and Column $C C$ of Table 2.

Results from Columns 1-4 in Table A-1 confirm our previous finding that the common factor hypothesis breaks down, statistically, when consumers are grouped not only according to their age but also according to their homeownership status. Including income (Column 2) and the real interest rate (Column 3) narrows the difference in the house price coefficients between the different groups. The elasticity of (old and young) homeowners' consumption to house prices drops from .36 to .27, the elasticity is the same for young renters, while old renters' consumption elasticity is only slightly lower. Economically speaking, the sizes of these last two elasticities are indeed very close in both specifications. Column 4 adds the log of family size as in $\mathrm{CC}$ and excludes some demographic and socio-economic variables, which results in old owners as the group with the highest elasticity of consumption to house prices. Yet, the size of the elasticity is still much lower than the size estimated by CC and the differences between the age-homeownership groups remain economically small. ${ }^{16}$ The common factor hypothesis breaks down not only in an statistical sense, but also economically, when replacing birth cohort dummies with birth-homeownership cohort dummies (Column 5 in Table A-1). The use of birthhomeownership dummies raises the coefficients of renters by 10 percentage points or more while reducing the coefficient of old homeowners. On the whole, young renters now show the highest sensitivity of consumption to house prices and young owners show the least. Although the introduction of birth-homeownership cohort dummies takes the specification closer to CC's, at this stage not only any confirmation of the common factor hypothesis has faded, but the wealth hypothesis is also plainly rejected. As in Table 2, the wealth hypothesis is only supported under $C C$ 's specification in Column 6.

\section{Appendix B: Correcting the UKDA Version of FES}

We detected two types of problems with the UK Data Archive version of FES used by CC. The first one is a missing data problem which concerns a) the expenditure category of "Clothing" and b) the wife's current income.

a) Data for "Clothing" are missing from October to December, from 1987 to 1993, and from January to March in 1994. CC recode these missing values to zero thus sharply increasing the variability of the series as well as that of the derived household specific price deflator. In this section, each missing year-month data is imputed a value obtained by multiplying the household's overall expenditure on all other non durable items in the relevant year-month by the share of "Clothing" in the household's total expenditure on all other non durable items in the same month of the nearest year available.

b) Data for the wife's gross current income are missing from September to December, from 1987 to 1994. CC recode these missing data to zero thus affecting their measure of household income defined as the sum of the head's and the wife's gross current incomes. Since the missing values

\footnotetext{
${ }^{16}$ Old owners' elasticity decreases slightly from .290 to .225 but becomes the highest among the four groups as the elasticities of young owners and young renters, which were in line with that of old owners up to this point, decline by around 2 percentage points. The elasticity of young owners also becomes similar, in size, to the elasticity of old renters.
} 


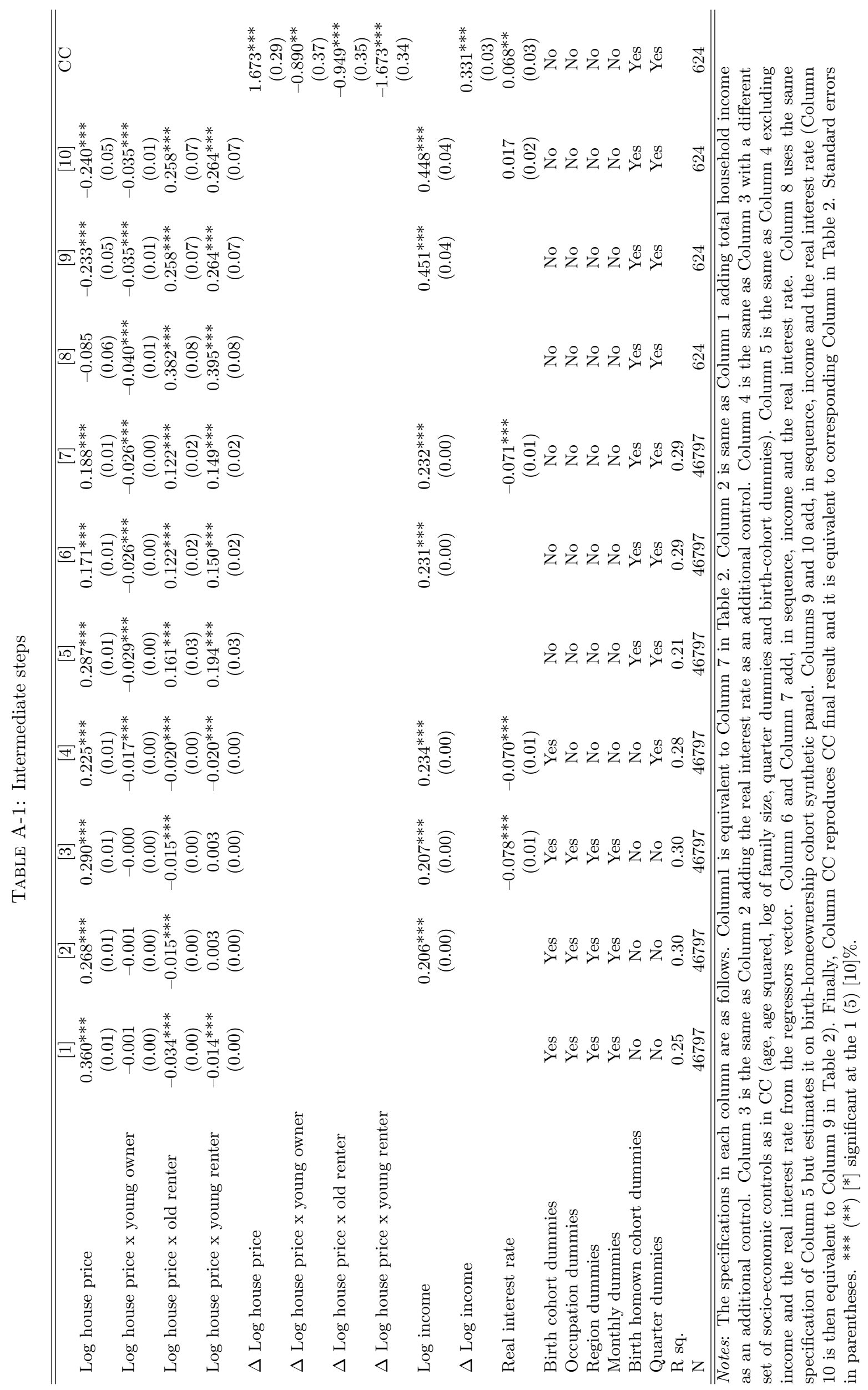


extend to all types of wife's incomes, we replace the measure of household income used by CC with the household gross current income available in the Archive with no missing values. Where both the sum of head's and wife's incomes and the overall household's income are available, the latter shows to be slightly higher, as expected.

The second problem is a coding error. Starting with the survey in the years 1993-1994, FES stopped collecting the data on the basis of solar years (i.e., from January to December of year $t$ ) and started collecting data on the basis of the financial year (i.e., from April of year $t$ to March of year $t+1$ ). For the surveys 1993-1994 and beyond, quarters need therefore be recoded (from 1 to 2,2 to 3,3 to 4 , and 4 to 1 ). However, the recoding has been accidently kept throughout the surveys in CC code, so that the quarters in the surveys from 1987 to 1993 are out of phase. Here we mend this error by limiting the quarters recoding to the surveys from 1993-1994 onwards.

Table B-1 shows some of the basic results presented in Table 2, using the corrected UK Data Archive version of the FES. Columns 1, 2 and 3 correspond to Columns 6, 7 and $C C$, respectively, of Table 2; Column 4 corresponds to Column $C C$ of Table 2 using data on a pseudo panel constructed only according to birth cohorts, as explained in Section ??.

Results from regressions in levels presented in Columns 1 and 2 do not differ substantially from those obtained using non-corrected data. Young and old households do not differ in their response to house price changes (Column 1) and when allowing for birth-homeownership groups (Column 2) differences, both between homeowners and renters and between old and young renters, are quantitatively small (in the order of 0.01 to 0.03 over the main effect of 0.35 ).

Finally, estimates of the CC Euler equation specification (Column 3) show that both old and young households respond to a house price change in a way that is independent of their being homeowners or renters and old households show an elasticity significantly higher than renters (1.8 vs 0.3$)$. Notice that this is virtually the same result we obtain when estimating the Euler equation using year of birth synthetic cohorts (Column 4). 
TABLE B-1: Corrections of the UK Data Archive version of the FES

\begin{tabular}{|c|c|c|c|c|}
\hline & {$[1]$} & {$[2]$} & {$[3]$} & {$[4]$} \\
\hline Log house price $\mathrm{x}$ old & $\begin{array}{c}0.337^{* * *} \\
(0.01)\end{array}$ & & & \\
\hline Log house price $\mathrm{x}$ young & $\begin{array}{c}0.341^{* * *} \\
\quad(0.01)\end{array}$ & & & \\
\hline Log house price $\mathrm{x}$ old owners & & $\begin{array}{c}0.348^{* * *} \\
(0.01)\end{array}$ & & \\
\hline Log house price $\mathrm{x}$ young owners & & $\begin{array}{c}-0.001 \\
(0.00)\end{array}$ & & \\
\hline Log house price $\mathrm{x}$ old renters & & $\begin{array}{c}-0.033^{* * *} \\
(0.00)\end{array}$ & & \\
\hline Log house price $\mathrm{x}$ young renters & & $\begin{array}{c}-0.013^{* * *} \\
(0.00)\end{array}$ & & \\
\hline$\Delta$ Log house price $\mathrm{x}$ old owners & & & $\begin{array}{c}1.778^{* * *} \\
(0.39)\end{array}$ & \\
\hline$\Delta$ Log house price $\mathrm{x}$ young owners & & & $\begin{array}{c}-1.445^{* * *} \\
(0.48)\end{array}$ & \\
\hline$\Delta$ Log house price $\mathrm{x}$ old renters & & & $\begin{array}{c}-0.579 \\
(0.46)\end{array}$ & \\
\hline$\Delta$ Log house price $\mathrm{x}$ young renters & & & $\begin{array}{c}-1.437^{* * *} \\
(0.46)\end{array}$ & \\
\hline$\Delta$ Log house price $\mathrm{x}$ old & & & & $\begin{array}{c}1.883^{* * *} \\
(0.36)\end{array}$ \\
\hline$\Delta$ Log house price $\mathrm{x}$ young & & & & $\begin{array}{l}0.487 \\
(0.31)\end{array}$ \\
\hline$\Delta$ Log total household income & & & $\begin{array}{c}0.266^{* * *} \\
(0.05)\end{array}$ & $\begin{array}{c}0.343^{* * *} \\
(0.08)\end{array}$ \\
\hline Real Interest Rate & & & $\begin{array}{l}0.029 \\
(0.04)\end{array}$ & $\begin{array}{c}0.023 \\
(0.04)\end{array}$ \\
\hline Birth cohort dummies & Yes & Yes & No & No \\
\hline Occupation dummies & Yes & Yes & No & No \\
\hline Region dummies & Yes & Yes & No & No \\
\hline Monthly dummies & Yes & Yes & No & No \\
\hline Birth-homeownership cohort dummies & No & No & Yes & No \\
\hline Quarter dummies & No & No & Yes & Yes \\
\hline R sq. & 0.24 & 0.25 & & \\
\hline $\mathrm{N}$ & 46792 & 46792 & 624 & 312 \\
\hline $\begin{array}{l}\text { Notes: Columns } 1 \text { and } 2 \text { are equivalen } \\
\text { equivalent to Column } C C \text { in Table } 2 \text { and } \\
\text { on synthetic cohorts constructed on the } \\
\text { ownership status in Column } 3 \text { ). Standar } \\
\text { the } 1(5)[10] \% \text {. }\end{array}$ & $\begin{array}{l}\text { to Colum } \\
\text { Column } 4 \\
\text { asis of age } \\
\text { errors in }\end{array}$ & $\begin{array}{l}6 \text { and } 7 \text { i } \\
\text { identical to } \\
\text { birth (as } \\
\text { rentheses. }\end{array}$ & $\begin{array}{l}\text { Table } 2 . \\
\text { Column } 3 \mathrm{~b} \\
\text { oposed to a } \\
* *(* *)[*]\end{array}$ & $\begin{array}{l}\text { olumn } 3 \text { is } \\
\text { t estimated } \\
\text { e and home } \\
\text { gnificant at }\end{array}$ \\
\hline
\end{tabular}

